\title{
Scenarios of Thailand Secondary Education within B.E. 2570
}

\author{
Bhayubhong Bhayuhah ${ }^{1}$, Chaiyuth Sirisuthi ${ }^{1} \&$ Preeda Lammana $^{1}$ \\ ${ }^{1}$ Faculty of Education, Mahasarakham University, Muang Mahasarakham, Mahasarakham Province, Thailand \\ Correspondence Bhayubhong Bhayuhah, Faculty of Education, Mahasarakham University, Muang \\ Mahasarakham 44000, Mahasarakham Province, Thailand. Tel: 66-89-942-2751. E-mail: \\ Krumoo101@gmail.com
}

Received: September 13, $2013 \quad$ Accepted: September 27, $2013 \quad$ Online Published: November 29, 2013
$\begin{aligned} & \text { doi:10.5539/ass.v9n17p291 } \\ & \text { URL: http://dx.doi.org/10.5539/ass.v9n17p291 }\end{aligned}$

\begin{abstract}
The objectives of this research were: 1) to study the current situation and problems of Thailand secondary education 2) to propose the Scenarios of Thailand Secondary Education within B.E 2570 by using EDFR (Ethnographic Delphi Futures Research) The $1^{\text {st }}$ Phase: the study of current situation and problems of Thailand secondary education. The $2^{\text {nd }}$ Phrase: the four steps of EDFR; Step 1 ( $1^{\text {st }}$ round of EDFR) expert interviews using a semi-structured interview, summary of possible trends by using NVivo. Step 2 ( $2^{\text {nd }}$ round of EDFR) trend analysis by using 12 expert questionnaires to find out Medians and Inter Quartile Range. Step 3 ( $3{ }^{\text {rd }}$ round of EDFR) the expert verification and consensus by using 12 expert questionnaires to find out Medians and Inter Quartile Range. Step 4 writing Scenarios of Thailand Secondary Education within B.E 2570. Research results showed that there were four aspects of current Thailand Secondary Education ; Learning and teaching aspects, Educational personnel aspect, Budget aspect, and Educational administration aspect. The Scenarios of Thailand Secondary Education within B.E 2570 would be 1) 12 possible trends of Learning and teaching aspects 2) 11 possible trends of Educational personnel aspect 3) 6 possible trends of budget aspect and 4) 10 possible trends of Educational administration aspect.

In summary, the Scenarios of Thailand Secondary Education within B.E 2570 according to this research could be conclude for the preparation of educational policy in secondary education which accord to educational plan of the office of education council to develop education with high efficiency and internationalize.
\end{abstract}

Keywords: scenarios, Thailand secondary education, B.E. 2570

\section{Introduction}

Education and learning system are parts of country development which must be linked to other development system. (Office of Upper Secondary Education. B.E. 2544:1) Secondary education is designed to develop the students' physical, intellectual, emotional and social to be good social members, good population as well as basic skills in their bold, interested career. In order to prepare students to study at a higher level, the secondary school provided teaching and learning to meet the learners' needs continued until the $11^{\text {th }}$ National Development Plan (B.E. 2555-2559). Educational policy reform defined the directions to improve the quality of new era of secondary education. The ministry of education has changed education for quality and standard students according to meet the current changes to be good citizen. These had their exactly ways of operations as secondary education quality administration operation. (announcement of the office of Basic Education Commission No. 621/2554 ) There are three related and supported elements; 1) educational management operations, 2) learning and teaching operations, and 3) supported supervisory. Ministry of Education organized appropriate learning and teaching processes to fit the needs of the students both academic and trait which accord with $2^{\text {nd }}$ decade educational reform policy (B.E. 2552 to 2561 ).

Thailand current education tried to be correlated internationalized by using educational reform approach according to announcement of the office of Basic Education Commission "the direction of new era of secondary educational quality development (B.E. 2553-2562) and $2^{\text {nd }}$ decade educational reform policy (B.E. 2552 to 2561 ). They were brought together to study under the educational scope and mission for the variety of efficient and sustainable components (McFarlance \& Ogazon, 2011) They were linked to Thailand educational management decentralize according to the National Education Act B.E. 2542. They started from the visionary leadership. Raihani (2008, p. 481-496) said that the strengthening organization must have quality leader and wide network 
to reach the success, so Thailand education recognized the importance of education in the place and environment of education. Paula Cardellino (2009, p. 249-262) has said that factors that significant affect in the school quality building in the $21^{\text {st }}$ century were learning environment, flexibility, inspiration, learning atmosphere support, and participation. The Florence D. Simmons (2011, p. 92) states that schools must be sponsored by government organizations, administrators and educators who had better understanding about the use of technology in the $21^{\text {st }}$ century learning skills in order to correlate to the past and present social effectiveness. The curriculum used for the cooperation of the family, business sector, and the community including the integration of technology, project based learning, Ongoing staff development. Using technology to develop Thailand education, learners can learn unlimited. Cathleen L. Ovravetz (2011, p. 86) states that technology can enhance education system to prepare students to live in the current technological environment effectively. They can communicate fluently and with quality. Steve Jose Martine (2011) suggested that to prepare students for the $21^{\text {st }}$ century skills must have critical thinking skills and problem solving skills. Wagner (2008) stated that students must have skills of leadership, and technology skills. So Thailand education must be well managed in every aspect to provide sustainable education and can be comparable internationally.

Nowadays the problems need to improve and develop are the educational opportunities support, the basic education quality, the capacity of the country is still low and added administration and education management (Office of the Secretary of Education B.E. 2554). Thailand educational has developed in order since the announcement of the B.E. 2542 National Education Act (20 August, B.E. 2542) They had learning reform, organization structure, educational management and administration, teacher production, payment, and education finance. But there were some items still unsolved; 1) curriculum development especially local curriculum could not offer variety of needs. 2) Learners in informal learning had lower achievement test scores than national criteria while lifelong learning was still limited. 3) The number of drop out and leave out students were increased. 4) Learning materials were unsuitable. 5) Student transferring could not be available because the offices lacked of system understanding. (Office of the Education Council. B.E. 2552: 72 ).

Therefore, National Education Act B.E. 2542 delivered the good and efficient management system which has the authority to build up manage government education management and administration, and local administration. There were educational system, learning management, administration and educational management, teachers and government officer administration. They provided framework for the development of new quality management, the policy to development of future of secondary education in the next decade with borderless communication. The purpose of this reform also provided to improve students to be quality and ethical learners.

\section{Research Methodology}

The objectives of this research were: 1) to study the current situation and problems of Thailand secondary education 2) to propose the Scenarios of Thailand Secondary Education within B.E 2570 by using EDFR (Ethnographic Delphi Futures Research) The $1^{\text {st }}$ Phase: study the current situation and problems of Thailand secondary education. The samples are 350 secondary school directors. The $2^{\text {nd }}$ Phrase: propose the Scenarios of Thailand Secondary Education within B.E 2570 using 12 educational expert interviews. There were four steps; Step 1: expert interviews using a semi-structured interview, analyze elements of Scenarios of Thailand Secondary Education within B.E 2570. Step 2: The studying and summarizing of possible trends of Thailand Secondary Education within B.E 2570. The statistics were Means and Inter quartile range. Step 3: The confirmation possible trends of Thailand Secondary Education within B.E 2570 by educational experts. The statistics were Means and Inter quartile range. Step 4: The presentation of Scenarios of Thailand Secondary Education within B.E 2570.

\section{Results and Discussion}

\subsection{Secondary Education Status in Thailand}

Table 1. Thailand and problems of secondary school administrators

\begin{tabular}{lllllll}
\hline Thailand secondary education & \multicolumn{3}{l}{ Current situation } & \multicolumn{3}{l}{ Problems } \\
& X & SD & opinions & \multicolumn{1}{c}{$\boldsymbol{X}$} & SD & opinions \\
\hline 1. Learning and teaching aspects & 2.96 & 0.38 & average & 3.54 & 0.13 & more \\
2. Educational personnel aspect & 3.41 & 0.36 & average & 3.15 & 0.15 & average \\
3. Budget aspect & 3.55 & 0.32 & more & 3.21 & 0.20 & average \\
4. Educational administration aspect & 3.28 & 0.30 & average & 3.22 & 0.17 & average \\
Total & 3.30 & 0.32 & average & 3.28 & 0.09 & average \\
\hline
\end{tabular}


Table 1 shows that the level of opinions on the current situation of Secondary School directors were in the 'average' level. There was budget aspect in the 'more' level while Learning and teaching aspects, Educational personnel aspect, and Educational administration aspect were in the 'average' level. The level of problems of Secondary School education mostly were in the 'more' level; Learning and teaching aspects while Educational personnel aspect, budget aspect, and Educational administration were in the 'average' level aspect. The $2^{\text {nd }}$ Phrase: propose the Scenarios of Thailand Secondary Education within B.E 2570 using 12 educational expert interviews. The results of the study in four aspects; Learning and teaching aspects, Educational personnel aspect, budget aspect, and Educational administration aspect found as follows

\subsubsection{Learning and Teaching Aspect}

Table 2. Results of educational 12 expert interviews on learning and teaching aspect

\begin{tabular}{clcc}
\hline Data & \multicolumn{1}{c}{ Results of data analysis } & Expert & Coverage \\
\hline interview & Student screening & 6 & $50.00 \%$ \\
interview & Thinking, cooperating and learning approach & 11 & $91.66 \%$ \\
interview & ASEAN focus learning & 8 & $66.66 \%$ \\
interview & Life skills approach & 10 & $83.33 \%$ \\
interview & English learning & 6 & $50.00 \%$ \\
interview & Team teaching & 4 & $33.33 \%$ \\
interview & Learning for career & 7 & $58.33 \%$ \\
interview & Measurement of promising talent & 9 & $74.99 \%$ \\
interview & Learning by using educational tablet & 6 & $50.00 \%$ \\
interview & Moral and ethics & 4 & $33.33 \%$ \\
interview & Ability assessment & 12 & $100.00 \%$ \\
interview & Technology for learning & 10 & $83.33 \%$ \\
\hline
\end{tabular}

From Table 2 Results of educational 12 expert interviews on learning and teaching aspect

found that 12 scenarios of Thailand Secondary Education within B.E. 2570 mostly focused on ability assessment, thinking, cooperating and learning approach, life skills approach, technology for learning, and measurement of promising talent in order.

3.1.2 Educational Personnel Aspect

Table 3. Results of educational 12 expert interviews on educational personnel aspect

\begin{tabular}{clcc}
\hline Data & \multicolumn{1}{c}{ Results of data analysis } & Expert & Coverage \\
\hline interview & English using ability & 4 & $33.00 \%$ \\
interview & $21^{\text {st }}$ century skills & 10 & $83.33 \%$ \\
interview & Moral, ethics and role model & 8 & $66.66 \%$ \\
interview & Teacher ability development & 6 & $50.00 \%$ \\
interview & Technology using ability & 7 & $58.33 \%$ \\
interview & Teacher digital literacy & 6 & $50.00 \%$ \\
interview & Learning adaptation and accordance & 10 & $83.33 \%$ \\
interview & International student contest improving process & 5 & $41.66 \%$ \\
interview & New era teacher & 6 & $50.00 \%$ \\
interview & School in school activities & 3 & $24.99 \%$ \\
interview & Appropriate compensation & 7 & $58.33 \%$ \\
\hline
\end{tabular}


From Table 3 Results of educational 12 expert interviews on educational personnel aspect found that 11 scenarios of Thailand Secondary Education within B.E. 2570 mostly focused on $21^{\text {st }}$ century skills and learning adaptation and accordance, moral, ethics and role model, technology using ability, and appropriate compensation in order.

\subsubsection{Budget Aspect}

Table 4. Results of educational 12 expert interviews on budget aspect

\begin{tabular}{clcc}
\hline Data & \multicolumn{1}{c}{ Results of data analysis } & Expert & Coverage \\
\hline interview & Corporation school budget supporting & 11 & $91.66 \%$ \\
interview & Stakeholder involvement & 10 & $83.33 \%$ \\
interview & Accountability and transparency budgeting & 9 & $74.99 \%$ \\
interview & Enough budget allocation & 10 & $83.33 \%$ \\
interview & Budgeting expert & 9 & $74.00 \%$ \\
interview & Worthy budget & 12 & $100.00 \%$ \\
\hline
\end{tabular}

From Table 4 Results of educational 12 expert interviews on Budget aspect found that 6 scenarios of Thailand Secondary Education within B.E. 2570 mostly focused on worthy budget, corporation school budget supporting, stakeholder involvement, enough budget allocation, accountability and transparency budgeting, and budgeting expert in order.

3.1.4 Educational Administration Aspect

Table 5. Results of educational 12 expert interviews on educational administration aspect

\begin{tabular}{clcc}
\hline \multicolumn{1}{c}{ Data } & \multicolumn{1}{c}{ Results of data analysis } & Expert & Coverage \\
\hline interview & Leading and professional administrator & 6 & $50.00 \%$ \\
interview & Visionary leadership & 7 & $58.33 \%$ \\
interview & Moral, ethics, exemplary administrator & 8 & $66.66 \%$ \\
interview & Learning Management skill & 7 & $58.33 \%$ \\
interview & Lifelong learning center builder & 6 & $50.00 \%$ \\
interview & Learner development system & 8 & $66.66 \%$ \\
interview & Special ability improvement & 10 & $83.33 \%$ \\
interview & International contest school ability & 10 & $83.33 \%$ \\
interview & The adjustment of the Office for National Education standards and Quality & 2 & 16.66 \\
& Assessment (ONESQA). & &
\end{tabular}

From Table 5 Results of educational 12 expert interviews on Educational administration aspect found that 6 scenarios of Thailand Secondary Education within B.E. 2570 mostly focused on special ability improvement, international contest school ability, moral ethics exemplary administrator, learner development system, visionary leadership, and learning management skill in order.

3.2 Trends Verification and Conclusion in Scenarios of Thailand Secondary Education within B.E. 2570

All experts verified all trends of these scenarios of Thailand Secondary Education.

Learning and teaching aspects. The expert results verified 7 most possibilities with highly accord were 1) ability assessment 2) thinking, cooperating and learning approach 3) life skill approach 4) technology for learning 5) ASEAN focus learning 6) learning for career 7) student screening.

Educational personnel aspect. The expert results verified 10 most possibilities were 1) $21^{\text {st }}$ century skills 2) learning adaptation and accordance 3) moral, ethics and role model 4) technology using ability 5) appropriate 
compensation 6) new era teacher 7) teacher digital literacy 8) teacher ability development 9) international student contest improving process 10) English using ability.

Budget aspect. The expert results verified 5 most possibilities with highly accord were 1) worthy budget 2) corporation school budget supporting 3) stakeholder involvement 4) enough budget allocation 5) budgeting expert.

Educational administration aspect. The expert results verified 7 most possibilities with highly accord were 1) special ability improvement 2) international contest school ability 3) moral, ethics, exemplary administrator 4) learner development system 5) visionary leadership 6) Learning Management skill 7) leading and professional administrator.

\section{Discussion}

Scenarios of Thailand Secondary Education within B.E. 2570 that researcher concluded from 12 educational expert interview and analyze with computer program were verified by the same experts showed that 1) there were 12 trends of Learning and teaching aspects 2) there were 11 trends of Educational personnel aspect 3) there were 6 trends of budget aspect 4) there were 10 trends of Educational administration aspect.

\subsection{Learning and Teaching Aspects}

Student screening. The teaches screened students as function of the class teachers / mentor teachers. Teachers analyzed the data of students in person and them into 3 categories; normal, risk, and problem. This process accorded to the $2^{\text {nd }}$ decade of educational reform policy (B.E. 2556-2561) that focus on the development, ability, skills and student characteristics.

Thinking, cooperating and learning approach. These process of learning and knowledge management were taught in every course with real situation contents consistent concept with David Strahan. (2009, p. 16) Team working and teaching highly created an effective educational organization.

ASEAN focus learning. Thailand education to ASEAN's approach was the essential way to development the students with academic knowledge, curriculum development and adjusting learning process, the overall educational development, the supporting of using and preserving local dialects, the accuracy of using Thai language as well as English languages as the concept of Steve Jose Martinez (2010, p. 82) has said that to prepare students to be ready to $21^{\text {st }}$ Century, a Learning-Center leadership acted as the guardian of moral. The leader must set the values of the school. Learning, teaching and education young people to become better future citizens.

Life skill approach was knowledge-building that can create meaning skills to help students learned in every step by themselves consistent with the policy (Office of the upper secondary education. 2553: 24). They were essential skills to develop students in core basic skills, communication, action, using ICT to solve problem, to work with others, and ethics in the workplace.

English language teaching approach by providing students learned English as a first foreign language in International school, English program, or other program. These were provided in national educational curriculum. These also had curriculum of Learner-Centered Language Curriculum, Communicative Approach, Language for Specific Purposes, and Integrated Learning and along with the essential skills in the $21^{\text {st }}$ Century (Ministry of Education B.E. 2554).

Team teaching Method focused on more than 2 teachers' teaching closely in the same period. They started to design from their learning objectives, lesson plan, classroom management, classroom activities, also classroom evaluation or assessment consistent with the concept of David Strahan. (2009, p. 16) said that teaching and working as a team with the responsibility can create co-efficient organization.

Learning for career was managed for developing knowledge, ability, and personal career skills. They used group procedure, self study as the concept of Stephanie Bell. (2010, p. 6) noted that learning in the future; Project-based learning is one of the innovative teaching methods that can create curiosity in students and demonstrate the power of learning through seeking absolute knowledge.

Measurement of promising talent by using a measure tools of the Bureau of the educational development, Ministry of Education to separate students into 10 ability groups 1) language group 2) math group 3) science group 4) movement group 5) music group 6) art group 7) social group 8) emotions group mechanics and electronic techniques, intellectual perception.

Learning by using educational tablet was the adaptation inside classroom by using technology, the study of system with technology, with the introduction of computer technology Tablet (Tablet PC). All media provided in 
this step accorded with the $21^{\text {st }}$ Century skills (Ministry of Education. B.E. 2554.) The Development of students learning skills was the key competencies of ability to communicate, to use technology, and consistent with the policy. (Office of the upper secondary education. B.E. 2553: 24). The basic necessary skills for the students to develop the use of ICT, communication, problem solving and working with others.

Moral and ethics system of education were factors in the coexistence in society. Cultivated moral conduct is determined in accordance with the Education Act regarding the desirable aspects of the study eight core courses and basic education central curriculum in 2551 mentioned that patriotic, religious, faithful king, honestly, discipline, living sufficiently, commitment to work, Thai culture loves, and public mind.

Ability Assessment was the process to evaluate teaching and learning while students had opportunity to present their opinions. The decision ability skills provided appropriate social practices consistent with the concept of Thomas Anthony Costello. (2011, p. 6) have summarized the skills that affect the achievement, interests, educational strategy, and academic achievement.

Technology for learning was available assisted classroom instruction with education designed program consistent with the concept of Amy Christen. (2009, p. 23) noted that Nowadays Students who able to access the Internet will be in a world of communication between people and the educational world unlimited.

\subsection{Educational Personnel Aspect}

English using ability. The operation. Education to improve their skills in English. English training for personnel at all levels of education. Development of education in each grade level have a basic knowledge of English is different. The concept of Laura H. King, Jennifer B. Williams, and Sandra H. Warren. (2011, p. 11) has said that teachers hold a new development model to target educational development. Teachers need to be aware of and understanding the diversity of teaching styles technology, an innovative teaching model.

The $21^{\text {st }}$ century skill consisted of classroom management, formulated together, and safety classroom manager accorded to the concept of Daniels (2010, p. 32) has said that promoting of teacher development started inside classroom by arranging rule and regularity for everyone accorded to the concept of Julie A. Brown (2011, p. 105) has said that teacher skills influenced to learner's ability and encourage students to learn more effectively accorded to the concept of Partin, Robertson, Maggin, Oliver, and Wehby (2009, p. 172-178) have said that teachers must have the skills and level of knowledge and competency based on research to enhance the efficient teacher 's classroom management accorded to the concept of Robert L. Linn, Chair (2008, p. 65) has said that while the students were learning, and success, the teachers should be trained or assessed in these things; curriculum management, learners' goals and teacher's talent.

Moral, Ethic and role model. Jugith Diane Northop (2011, p. 77) has said that teachers should have moral, understanding, compassionate to learners . Teacher were accepted, gained the trust in the highest level. There were honor, respect, and obedience. Teachers must have the ability to stimulate searching for information, understand culture and life accorded to the concept of Annie Elizabeth Honas (2011, p. 45) has said that teacher characteristics consisted of 1) knowledgeable and experienced outside the classroom, 2) ASEAN teaching confidence, 3) teacher intention and ethics, 4) supported from school administrators and other institutes.

Teacher ability development was the processes of teacher paradigm development in values, skills and knowledge, learner-centered approach, emphasis on the teacher identity, community knowledge service, learning and innovation skill development, basic skills of information communication technology, life skill, Global citizenship accorded to the concept of the Beach (1970, p. 375) noted that teacher development is a process designed to enable individuals to learn and expertise, to change people's behavior in a better way.

Technology using ability. Teachers use instructional texts to teach many years ago, now it is the era of information technology. Teachers need to be a technology expert with having basic computer knowledge in accordance with the changes of technology accorded to the concept of Laura H. King, Jennifer B. Williams, and Sandra H. Warren. (2011, p. 11) has said that the model to develop new era teacher should be educational development goals. Teachers need to be aware of their understanding of the ethnic diversity, teaching styles and innovative technology, appropriate teaching and the educational support.

Teacher digital literacy. Technology for teaching skills enlarged learner inspiration. For example, using Blog, Wiki, and Facebook as teaching and learning tools were provided learning anywhere and anytime. The variety contents in social media were efficiently used in various subjects accorded to the concept of Cathleen L. Ovravetz (2011, p. 86) has said that technology can enhance educational system to prepare students to live in the current technological environment effectively.

Learning adaptation and accordance started inside teachers ability, skills and readiness to improve their teaching 
accorded the concept of Emmer \& Gerwels. (2005) stated that classroom management is the process of learning by the learner in the classroom. The rules selection consisted of students preparing, creating friendly atmosphere for the beginners, planning and good teaching.

International student contest improving process. The current model of creating students has changed from in the past. Teacher have to pay more attention and understand the students via variety educational environment accorded to the creative mind of the idea of Donovan A McFarlance and Agueda G. Ogazon (2011, p. 107) has said that sustainable education meet the changes of the new era has to completely change to universal sustainable education.

New era teacher. Teacher should add more roles in classroom and using technology accorded to the concept of Laura H. King, Jennifer B. Williams, and Sandra H. Warren. (2011, p. 11) have said that the model to develop new era teacher empowered teachers to understand the diversity of teaching styles and innovative technology.

\subsection{The Budget Aspect}

Cooperation school budget supporting. They were checked and controlled by in school inspectors or outside committee. The continuous transparency checking lead to the useful advantage education system accorded to the accordance with the Basic Education Commission. (2550, p. 3-6) noted that community participation in budget checking, money, and learning management for sustainable education and internationalize.

Stakeholder involvement showed the connection between the resources spent on returns shall be consistent with the principles and procedures for administrative decentralization and education 2550. (Gazette. 2550: 29) the administration's budget to focus on education, decentralization of management flexibility and transparency can be checked. Management principles focus on achievement and budget management focuses on performance (Performance-Based-Budgeting: PBB).

Accountability and transparency budgeting. The current situation emphasis on independence, flexibility, transparency, monitoring, The principles of management focus on achievement and performance accorded to the classification of funds regulations of the Office of Basic Education Commission (2551: 1-10).

Enough budget allocation. Funds must be distributed to the school at least $80 \%$, the remaining $20 \%$ for central management. Every school should examine and use "sufficiency economy" that helps to Self-discipline, decrease expense by using recite energy. The results reflected to have enough budget accorded to the establish rules and procedures for administrative decentralization and education 2550 (Government Gazette. 2550: 29) The school budget management focused on the distribution of power in the administration to be transparent and flexible. Principles of management accountability and focus on results-oriented budget management performance (Performance-Based-Budgeting: PBB).

Budgeting expert. The expert worked with effective financial statements and accounting principles to ensure efficiency and effectiveness accorded to the regulations of the Office of Basic Education Commission has been the classification of funds (2551: 1-10) in the financial management of the school budget.

Worthy budget management with the most benefit supported the efficiently school administration. They clarify and ensure the correct of using school budget accorded to the regulations of the Office of Basic Education Commission (2551: 1-10) in the financial management of the school budget.

\subsection{Educational Administration Aspect}

Leading and professional administrator. The administrators or leaders have to improve quality of education, create effective learning organization, and facilitate all surround knowledge.

Visionary administrator. The visionary school administration changed the overall educational situation in such school that lead to present the whole national education level in the national competition accorded to the concept of Mike Bosy. (2007, p. 32) has said that the revolutionary of changed leadership, effected to the challenge of changed education.

Moral, ethics, and exemplary administrator. Administrators created modern process of practicing that are consistent with the changes, personality, and vision accorded to the concept of Policy education reform in the second decade (B.E. 2556-2561) that requires academic leadership administrators with oversight, supervision, learning and update regularly for the community, the developer of teachers teaching.

Learning management skill. They provided their routine work as the knowledge manager for all teachers, students, and participants according to each competence accorded to the concept Steve Jose Martinez (2010, p. 82) has said that preparing students for the 21st century, the leaders or administrators must serve important functions as a moral guardian that lead to determine the values of justice and school disciplinary 
action as a community.

Lifelong learning center builder. The administrator must facilitated the habits of learning, involved of parents to organize the students learning, critical thinking, using medias to promote the students skills accorded to the concept of Thaddues J. Peters. $(2012$, p. 14) has said that the involvement of parents of students with behavior and student academic achievement, the motivation and creation of learning atmosphere at students home.

Learner development system. The development focused on teaching and learning system, students' content of knowledge and expertise. The administrator planned institutional curriculum to educate subjects and forms of interdisciplinary learning. Parents participated by providing information and tools for the teaching and learning of the real world accorded to the concept of Thaddues J. Peters. (2012, p. 14) has said that the involvement of students parents influence student academic achievement .Status of the parents affect the academic achievement of students, but reflect the motivation and create an atmosphere of learning at home accorded to the concept of Florence D. Simmons (2011, p. 92) has said that the school will be sponsored by the government. Administrators and educators with a better understanding about the use of technology in the 21 st century learning skills in order to maximize the effectiveness of past and present society. The concept of Paula Cardellino (2009, p. 249) has said that the major factors affecting the quality of the school Environmental learning is flexible, inspire, promote learning atmosphere and participation.

Specific ability improvement. The need to prioritize and focus on the learner were 1) allowing learners to participate in learning activities, developing science aspects in the age of globalization, effecting the need for change and improvement throughout the course of the study accorded to the concept of Gatoni, W. (2007, p. 205-211) has concluded special educators and general educators are faced with new challenges when trying to find the different needs of the students in the class. As a method of classroom management strategies that are most effective in the management of appropriate behavior and achievement.

International contest school ability. School education provided wider dimension, boundless, the more liberalized education for ASEAN accorded to the concept of Andrew Targowski. (2011, p. 23) has said that a new civilization of education, global changes impacted on education at all levels. The educational leaders must face the fact that pre occur with the knowledge and savvy to change.

The adjustment of the Office for National Educational Standards and Quality Assessment (ONESQA) needed to evaluate the suitability and reliability increased. For the reasons to evaluate the national forms of ONESQA. The assessment takes lot of time accorded to the concept of Office of the Senior High School (2553, p. 10) has proposed that the management of the quality management system has been certified by the standards organization.

\section{Conclusion}

The research results created totally 4 scenarios of Thailand secondary education within B.E. 2570 to be policy guidance for secondary education. These were accorded with the education plan of the Office of the Education Council to improve teaching and learning efficiently and to increase the international standards.

\section{References}

Beauchamp, G. A. (1964). The Curriculum of the Elementary School. Boston: Allyn and Bacon.

Brown, J. A. (2011). A Delphi Study of Best Practices for the Achievement of English Language Learners. Walden University.

Cardellino, P. (2009). Exploring the Role of Design Quality in the Building Schools for the Future Programme . Architectural Engineering and Design Management, 5. http://dx.doi.org/10.3763/aedm.2008.0086

Costello, T. A. (2011). Achievement Goals, Interest, Study Strategies, and Academic Achievement. Fordham University, New York.

Daniels, V. (2010). How to Manage Disruptive Behavior in Inclusive Classroom? Retrieved from http://teachervision.fen.com/classroom discipline/resource/2943.html development plan. Prime minister office: 2555 .

Emmer, T., \& Gerwels, M. (2005). Classroom Management for Secondary Teachers. Retrieved from http://eric.ed.gov/ERIC

Gatoni, F. (2007). Person-Center Approach in School: Is It the Answer to Disruptive Behavior in Our Classroom? Counseling Psycholofy Quarterly. 
Honas, A. E. (2011). Practices of Two Experiential Teachers in Secondary Public School in $\quad$ an $\quad$ Era of Accountability. Western Carolina University.

King, L. H., Williams, J. B., \& Warren, S. H. (2011). Preparing and Supporting Teachers for the $21^{\text {st }}$ Century Expectations through universal Design for Learning. Morality in Education, Winter.

Linn, R. L. (2008). Student Learning, Student Achievement. How Do Teachers Measure up? National Board for professional Teaching Standards.

Martinez, S. J. (2010). Survival in Global Village: A School Model with $21^{\text {st }}$ Century Students. University of Southern California.

McFarlance, D. A., \& Ogazon, A. G. (2011). The Challenges of Sustainability Education. Journal of Multidisciplinary Research, 3(3).

Ministration of Education. Thailand educational policy for $21^{\text {st }}$ century skills. Bangkok: Religion printing 2554 .

Northop, J. D. (2012). Teacher and Student Relationships and student outcomes. University of Corolado Denver.

Office of academic and education standard. School curriculum management. Bangkok. 2551.

Office of committee of national economic and social development. $11^{\text {th }}$ National economic and social

Office of upper secondary. Network for development and empower. Bangkok: 2553.

Office of upper secondary. New secondary era toward B.E. 2561. Bangkok: Work for development and empower. Bangkok: 2553. Thailand agriculture cooperation printing. 2554.

Office of upper secondary. Strategic driven manual. Bangkok: 2553.

Office of upper secondary. Teaching and learning development. Bangkok: 2553

Ovravetz, C. L. (2011). Assessing Middle School Student Participation in Online vs. Face to Face Environments. Northeastern University, Boston, Massachusette.

Simmons, F. D. (2011). A Case Study of School's Program to Prepare Students for Real Work in the $21^{\text {st }}$ Century. St. John University. New York.

Targowski, A. (2011). The Civilization Approach to Education in the $21^{\text {st }}$ Century. Comparative Civilizations Review, Fall(65).

The Office of Basic Education Commission. Labschool project learning resources. Bangkok: Semathum, 2550.

The Office of Basic Education Commission. Manual of educational school bursary. Bangkok: Agricultural cooperation meeting of Thailand, 2551.

Bossi, M. (2007, May-June). Revolutionary leadership. Leadership, 36(5).

Peters, T. J. (2012, January). Parental Involvement: How Does It Relate to Student Behavior and Academic Success? Capella University.

\section{Copyrights}

Copyright for this article is retained by the author(s), with first publication rights granted to the journal.

This is an open-access article distributed under the terms and conditions of the Creative Commons Attribution license (http://creativecommons.org/licenses/by/3.0/). 